Diana Lj. Prodanović Stankić ${ }^{1}$

Faculty of Philosophy, University of Novi Sad
UDK-378.147::811.111

D0I:10.5937/nasvas1703515P

Оригинални научни рад

НВ год. LXVI 3/2017

\title{
PEER FEEDBACK AS A COLLABORATIVE TASK USED IN IMPROVING WRITING SKILLS: A CASE STUDY
}

\begin{abstract}
Learning to write in English as a foreign language has become one of the basic skills for those who need and want to read and produce academic discourse. The problems of EFL learners in connection with writing are usually related to the transfer of knowledge of their mother tongue in terms of lexical structures, text conventions and line of argumentation. In that context, error treatment and adequate feedback have a huge impact on the level of attainment and progress in the field of writing. The aims of this small-scale study were to find the correlation between different types of feedback and types of learning, and to determine the effects of these variables on the level of attainment of students in reference to specific written assignments. Both quantitative (descriptive statistics based on the percentage share within the structures of the categories) and qualitative methods were used. The results of the study indicate that the preferences for a specific type of feedback are culture-specific and that a collaborative task-based approach had a positive impact on improving specific skills related to writing and giving and receiving feedback. The findings led to the suggestion to include more of these activities in curricula and to redesign assessment methods as providing and responding to adequate feedback has huge pedagogical implications for deep learning.
\end{abstract}

Keywords: EFL, writing in a foreign language, feedback, collaborative task-based approach.

\section{Introduction}

As one of the essential communicative skills, writing is an indispensable part of any EFL course. Typically, it is taught either separately or it is fused with other productive and receptive skills in courses based on an integrated approach to language learning. For non-native speakers, writing in English is one of the most challenging skills they need to acquire. Regardless of their level of knowledge, they usually struggle with writing conventions, based on culture-specific cognitive and textual structures and various levels of language use: syntactic structures, vocabulary, register, etc.

Yet, it seems that with the global dominance of English, most notably in publishing, writing in English is closely linked to visibility in any academic career or field of study, and in that way it has become a prerequisite for advancement. Teachers have always put a strong focus on acquiring and improving writing skills, not just to cater for the needs of

1 E-mail: diana.prodanovic.stankic@ff.uns.ac.rs 
graduate students in terms of career prospects, but also to put the input they teach to use and assess their students' level of attainment.

The main idea behind this paper is related to practical pedagogical concerns in the EFL classroom. In the context of teaching Integrated Language Skills (ILS) at the tertiary level, the focus on writing skills is mainly directed towards the overall goal of reaching a good level of competence in academic writing. During the process of learning how to master writing skills, students typically receive plenty of tasks and a lot of written and oral feedback in reference to their written assignments. The aim of this paper is to report on the findings of a small-scale study conducted in the undergraduate courses Integrated Language Skills 3 and 4 at the Department of English Studies, Faculty of Philosophy, University of Novi Sad. In the study, the students had to write two written assignments as part of their course requirements, and the teachers' written feedback alongside with students' reactions to it were analyzed in order to determine to what extent the given feedback was useful and beneficial for students. Also, another aim was to see how feedback could be transformed into a meaningful and task-based practice designed so as to improve students' revision and proofreading skills.

\section{The Development of Students' Writing Skills in EFL}

The courses Integrated Language Skills 3 (ILS 3) and 4 (ILS 4) are obligatory courses in the second year of the four-year Bachelor's Degree Programme at the Department of English Studies, at the University of Novi Sad, Faculty of Philosophy. The main objectives of the courses involve improving all language skills in order to attain a near-native fluency both in speaking and writing at the end of the programme. By the end of the academic year, it is expected that the students will have reached C1-C2 level of the Common European Framework of Reference for Languages - CEFR (2011).

Specifically, when it comes to writing, at the beginning of the second year, students are basically just familiar with the most typical forms and genres; their writing experience is rather limited, since they focused mainly on different stages of the process in the first year. According to the outcomes of the course, students should be able to write clear, well-structured and detailed texts approximately 300-350 words long, in the appropriate style and register and following the established conventions of the genre concerned. For example, they should be able to write both informal and formal letters, proposals, reports, reviews, newspaper articles and essays. After graduating, the great majority of the students will enrol in a Master's Degree Programme and writing in English and being familiar with writing conventions will be a necessary precondition for postgraduate study programmes. As Silva (1990: 16) put it, "learning to write is part of becoming socialized to academic community - finding out what is expected and trying to approximate it."

Learning how to write in a foreign language imposes additional difficulties for a student who has to master not only the language skills but writing conventions typical of a different culture as well. In this context, as Kroll (1990: 2) rightly observes, teachers must be aware of the fact that "first language literacy skills may transfer to or detract from the acquisition of second language skills." It must be stressed that in the Serbian context, text conventions, as well as some concepts related to it, are different from the ones accepted 
and followed in writing in Anglophone cultures (Blagojević, 2012). For example, in terms of using rhetorical strategies in writing, English and Serbian differ significantly, in particular concerning the use of the concept of academic politeness and persuasiveness. English writers tend to use hedging devices more frequently (17.3\%) than Serbian (9.5\%), since in English it is considered too presumptuous to show explicitly one's authority. That is the reason for using less emphatic linguistic devices to persuade and argue in English, as opposed to Serbian (Blagojević, 2012: 1936-1937). As Connor (1996: 10) argues, not just the linguistic, but also the culturally-bound assumptions about the nature and the purposes of written texts can transfer from $L 1$ to $L 2$.

Considering a whole range of specific needs students have regarding the improvement of their writing skills, the approach to writing that is used in the courses ILS 3 and ILS 4 is a combination of a product, process and genre-based approach. The main focus, though, is on the process approach. The product-oriented approach to writing focuses on mechanical aspects of writing, in the first place on grammatical and syntactical structures. Nunan (1999: 272) states that the role of the teacher is to provide model language and guided exercises, and to correct errors when the final product is created. In the context of this particular study, this approach was used at the beginning of the course when the teacher had to determine the level of students' knowledge related to writing skills and when there was a need to revise some grammatical structures.

As opposed to the product-oriented approach, the process-oriented approach focuses more on the process the writer goes through, from brainstorming and generating ideas to revisions of the final version. In the classroom this translates into group brainstorming exercises, general discussions, and group planning activities to decide on the content of the piece of writing. Peer correction and group evaluation are also encouraged. According to Silva (1990: 15), "the process approach calls for providing a positive, encouraging, and collaborative workshop environment within which students, with ample time and minimal interference can work through their composing processes." Unfortunately, being faced with a whole range of course objectives, teachers usually cannot provide ample time in class. Yet, the focus on the process itself is still essential, as helping students handle different stages of the process can have a positive impact on their progress.

Finally, the genre-based approach focuses on the text as a way to communicate with readers. The aim is to teach learners how to "write something to achieve some purpose" (Hyland, 2003: 18). In this approach, students are instructed to take the overall social purposes of a text into account when composing a text. Specifically, in the given context, the genre-based approach was used when students had to learn the conventions of some specific text types, for example, writing motivational letters. Also, the task they got always included specific information regarding the prospective target readers, information they had to include, etc.

Due to EFL students' specific needs, using models to prompt students to use more complex structures and a specific organization turned out to be helpful as well. This becomes even more evident in situations in which the teacher's and students' expectations regarding the students' final written product do not match or in which the given feedback does not result in significant improvement considering either grammatical accura$c y$, the use of more complex grammatical structures or specific vocabulary, organization and/or content. 


\section{The Role of Feedback}

In order to achieve their different communicative goals and increase students' motivation in the EFL classroom, teachers have to provide a lot of feedback. Timely feedback seems to be essential for both students' motivation and consolidation of the language they have learnt. As much as it seems to be the pivotal element in the process of learning how to write, as Hyland and Hyland (2006: 83) claim, the effects and the role of feedback in the relevant literature and research are rather ambiguous and underused.

"Feedback should be an interactive part of the whole context of learning, helping to create a productive interpersonal relationship between the teacher and the individual students" (Hyland and Hyland, 2006: 86). Its functions range from praise and suggestion to error correction and criticism, yet there remains little agreement on what kind of marking is effective. For example, some authors (Fazio, 2001; Truscott, 1996; 2007) argue that corrective feedback is ineffective due to several reasons: it does not affect learner's ability to write accurately and it discourages students from using more complex grammatical structures or a wider vocabulary range for fear of making errors.

In response to students' products of writing, in the courses ILS 3 and ILS 4, typically two types of feedback are given: direct and indirect, following the classification given in Ferris (2003: 162) and it is given in two forms, oral and written. Ferris (2003: 162) argues that indirect feedback, when the teacher does not provide the correct or preferable answers is preferable for EFL students, because it engages them in "guided learning" and affects progress much more than direct feedback, in which the teacher provides the correct form.

Oral feedback is typically given in class in form of a short summary focusing on some good points students made or on the typical errors. In the communicative approach to language learning this type of feedback is emphasized. However, it is not too detailed and its aim is to summarize the main points and raise awareness of most common errors. In addition to this, its aim is to develop students' metacognitive skills and their own ability to revise and proofread their own product of writing. More detailed oral feedback is given during the teacher's office hours, when he/she can discuss all the problematic aspects with the students individually.

The relevant literature is still inconclusive regarding the benefits of feedback based on error correction for students' writing skills development (Chandler, 2003; Truscott, 1996; 1999). However, as Hyland and Hyland (2006: 85) argue, "feedback alone will not be responsible for improvement in language accuracy, but it is likely to be one important factor." It seems that its significance is closely related to the fact that feedback provided in time represents a kind of formative assessment that has a crucial role in developing students' metacognitive skills as well as their internal motivation for their learning progress.

Black and Wiliam (1998: 140) define assessment broadly to include all activities that teachers and students undertake to get information that can be used diagnostically to alter teaching methods and learning. Under this definition, assessment encompasses teacher's observations, classroom discussion, and the analysis of students' work, including homework and tests. Assessment becomes formative when the information is used to adapt teaching methods and style and learning to meet students' needs. When teachers know their students' progress and level of attainment and when they can pinpoint students' areas of difficulties, they can use this information to make necessary changes in their approach: they can revise the lessons, use an alternative approach, provide more 
time for practice, etc. All of these activities are aimed at improving students' level of attainment. In their research, Black and Wiliam (1998) have shown that formative assessment has the greatest effect on low-achieving students and students with learning disabilities.

\section{Task-Based Approach}

In the courses ILS 3 and ILS4, the teaching style is based both on content-based language learning and task-based instruction. The main idea behind task-based instruction is to involve students in an in-class activity that encourages comprehending, manipulating, producing or interacting in the target language, focusing attention mainly on meaning (Nunan, 2004). According to Oxford (2001), tasks are defined as activities that can stand alone as fundamental units, and in task-based instruction, basic pair work and group work are often used to increase student interaction and collaboration.

While working towards autonomy in the foreign language, especially at the tertiary level, students should be offered a lot of scaffolding, as it affects language use and learning to a great extent. Vygotsky's (1978) concept of scaffolding draws on the socio-cultural theory, and as Ellis (2000: 194) argues, "this approach views language learning as socially constructed through interaction of one kind or another". In that context, tasks can be regarded as workplans that are tailored to the specific needs of each particular student, which is of utmost importance at any level of education. Ellis (2000: 195) defines a task as "a workplan that typically involves the following: (1) some input (i.e. information that learners are required to process and use); and (2) some instructions relating to what outcome the learners are supposed to achieve." As Min (2005: 294) has it, a task based on peer review will benefit students more "when partners have different areas of competence and interact positively in oral or written communication that includes questioning, providing elaborate responses and instructing." During that process, it seems that the development of writing skills can be facilitated by the active involvement of peers, especially when we consider some stages of the process of writing, such as drafting, planning or feedback (Ferris, 2003; Hyland, 2003).

Skehan (1998) adopts a so-called 'cognitive approach' to support his empirical investigations of tasks. In line with this approach, learners construct both an exemplar-based system and a rule-based system. According to Skehan (1998) the former is lexical in nature, containing separate lexical items and ready-made formulaic chunks of language easily accessible in given situations. The latter includes abstract representations of the underlying patterns of the language that require more processing, employed mostly in more controlled situations, when the focus is more on accuracy rather than fluency.

In this study, the focus will be on peer response as a collaborative task that can be used to increase students' metalinguistic awareness, their ability to identify and explain the nature of problems, mostly those related to content and organization, and their ability to provide constructive specific suggestions.

\section{Research Methodology}

\section{The Aims of the Study}

The aim was to explore students' perceptions and preferences regarding feedback in order to determine how it affects their writing. The other aim was to explore the potential 
of using collaborative task-based work in order to measure the amount, quality, relevance and adequacy of peer feedback. Basically the idea was to investigate the kind of revision the students engage in while working in pairs, as well as the strategies they use in this process.

\section{Participants and procedure}

The participants in the study were 50 second-year undergraduate students majoring in English at the Department of English Studies, Faculty of Philosophy, University of Novi Sad. The participants in the study were 20-21 years old, 33 female and 17 male. Serbian was the mother tongue of 46 students, 3 students were native speakers of Hungarian and one of Slovak. The study lasted two semesters in the academic year 2014-2015 and took place in the courses ILS 3 and 4. Due to the fact that these courses are obligatory, all the students had to do the same tasks required by the course specification, so the data could not be compared between a control and test group.

Research data was collected through a questionnaire and students' feedback provided in collaborative tasks. The questionnaire consisted of five closed-ended questions which were designed on three to five extensions that measured the relative degree of importance of an item and the data obtained was analyzed by means of descriptive statistics based on the percentage share within the structures of the categories. The peer feedback was analysed in terms of accuracy (in terms of specific elements that it referred to: organization, content, coherence, correctness, relevance).

\section{Research Results}

As previously mentioned, the first research question was aimed at discovering students' perceptions and preferences regarding feedback in general, as well as specific types of feedback. All the students were positive about the importance of the teacher's feedback for the development of their writing skills (100\%), although they rated it differently.

Table 1. Students' evaluation of feedback in general

\begin{tabular}{lc}
\hline & The number of students (\%) \\
\hline extremely important & 9 \\
very important & 68 \\
quite important & 17 \\
somewhat important & 6 \\
unimportant & 0 \\
\hline
\end{tabular}

Taking into account the extent to which teacher's feedback in general affected their writing skills in English, 76\% were positive about it, and $8 \%$ of the students thought it did not have a significant impact and $16 \%$ of them were neutral about this statement. 
Prodanović Stankić, D. Peer Feedback as a Collaborative Task... • НВ год. LXVI бр. 3/2017, стр. 515-526.

Table 2. The effect of teacher feedback on students' writing skills

\begin{tabular}{lc}
\hline & The number of students (\%) \\
\hline positive impact & 76 \\
no significant impact & 8 \\
N/A & 16 \\
\hline
\end{tabular}

The great majority of students preferred teacher to peer feedback ( $82 \%$ to $7 \%$ ), though $11 \%$ had no opinion about this question. The students in general preferred direct corrective feedback (92\%) to indirect ( $8 \%$ ) since they welcomed comments that require grammar accuracy and were more likely to revise their drafts upon receiving such comments.

Table 3. The preference for teacher or peer feedback

\begin{tabular}{lc}
\hline & The number of students (\%) \\
\hline teacher's feedback & 82 \\
peer feedback & 7 \\
N/A & 11 \\
\hline
\end{tabular}

This finding is in opposition to Ferris and Roberts's (2001: 166) statement based on several similar studies, in which students indicated that they preferred indirect feedback with error codes or labels attached over either direct teacher correction or errors being simply marked but not labelled. Generally, students prefer specific corrective feedback aimed locally (96\%) to feedback that is indirect and aimed at global features such as ideas, content, style or organization. Paradoxical as it is, it is precisely the global aspects of written assignments that the students have most problems with at this level.

The other aim of the study was to evaluate peer feedback after revising collaboratively the motivational letter for an exchange programme students wrote individually. Basically they had to provide feedback for two letters, and they did this task in pairs. First they had to give indirect feedback focusing both on the global and local features of the letter and direct corrective feedback for the second letter, again focusing on both global and local features.

In another task, all the students were supposed to transform the teacher's indirect feedback into direct. The feedback was given in reference to another written assignment the students wrote during the course, a formal essay. To illustrate the assignment - if a specific word or phrase was underlined or marked using the marking system for editing and proof reading familiar to students (e.g.,$- \approx \approx \approx \approx \approx \approx \approx \approx$, etc.), students had to provide specific corrective feedback, such as "a definite article is missing, or "S-V Agreement", etc.).

After analyzing the feedback students provided and shared with their peers, it must be said that the students' feedback was quite elaborate and detailed and in most cases adequately targeted the problematic areas. While proofreading other students' work, they were quite capable of assessing the global features of a text and providing comments on this aspect of the written assignment, though this certainly was the most problematic issue when they themselves went through the revision process of their own written 
products. When the comments they provided on their peers' assignments were compared to the teachers' comments, it turned out that there was a substantial coincidence between them (87.3\%), which may imply that raising students' awareness of metalinguistic properties of a text may affect their proofreading and subsequently their writing skills.

\section{Discussion}

The results of this study suggest several aspects that need to be taken into account while teaching and assessing writing skills. First of all, in reference to the micro-level of students' writing and the level of accuracy, it must be mentioned that despite the fact that most of the students who participated in the study had passed (successfully) the theoretical course in English grammar, they still had difficulties with language use in specific situations. The most problematic areas on the micro-level were closely related to the use of articles, sequence of tenses and prepositions, as well as word order in more complex structures.

In terms of vocabulary use, students generally had problems with collocations, semantic precision and the use of appropriate register. Specifically, they had a general tendency to use informal language and even slang in formal argumentative essays or formal letters, such as a motivational letter. It is interesting, though, that the errors they made related to the inappropriate use of registers decreased while they worked collaboratively. Observation of the process of writing indicated that collaborative discussions increased students' awareness of different stages of the very process of writing.

In that sense it seemed that they reminded each other to pay attention to the target readers of their product of writing, for example, which they otherwise tend to forget, and hence end up with an inappropriate register choice. Also, when the students had to mark and check their peers' written assignments, they were more aware of the text conventions, as well as the need to achieve cohesion and coherence, both at the level of paragraphs and the whole piece of writing. In that context, they were quite capable of proofreading written assignments and had fewer difficulties both with the macro and micro structure of the text when they discussed various aspects of it with their peers.

Additionally, it seems that they paid more attention to content with regard to developing ideas and arguments, something that they generally struggle with. Although they have a tendency to transfer elements of knowledge or perhaps even to translate from L1 to $L 2$ while writing in $L 2$ on their own, when faced with a collaborative task of proof-reading they could more easily assume the role of a proficient L2 speaker. In that way, the transfer of L1 to L2 was kept under control and they displayed greater fluency in L2 as well as awareness of text conventions typical of $L 2$.

The results of this study corroborate Silva's (1993) findings in terms of students' attitudes towards the revision of their own texts. Once they are over with writing, they usually revise their final written product only superficially, primarily focusing on structural and grammatical errors, and rarely on errors related to composition, argumentation or organisation. This has a wider implication for designing courses and creating syllabi, as more time should be devoted to practising revision and self-monitoring skills. 
It should be pointed out that the results of the study that indicated better control of the $L 1$ to $L 2$ transfer either in writing or proofreading are not completely in accordance with the students' preferences regarding the type of work. Namely, even though many found that a collaborative approach to the given assignment could serve as an incentive for their motivation and level of accomplishment, there were still many students who preferred individual activities and refrained from being involved in reasoned discussions. Their arguments in support of this attitude were based on the fact that writing is by default a solitary activity, and for that reason, it was difficult to share other people's insights. This is to some extent culture-specific, as in the Serbian context, the majority of students are not used to sharing responsibilities in team work, and prefer working on their own.

Despite the fact that this study is small in terms of the number of participants and the scope, and although its reliability should be tested on a larger number of students and a wider range of activities, it is evident that the efficiency of both the teaching and learning styles in the classroom can be improved. Feedback is a case in point as it should be regarded as an incentive for students to raise their self confidence related to the use of language and editing skills.

Moreover, the findings of the study indicate that there is a need, at the tertiary level of education, to move away from assessment that is aimed exclusively at the final product. To some extent, assessment of the very process of writing, and not just of the final product, should be included in the marking scheme, as that would make students more aware of the necessity of going through all the stages of the writing process. The same applies to team and group work. Teachers need to raise students' awareness of the advantages of developing team work skills and collaboration among peers, as this is one of the essential work skills required by prospective employers. For that purpose the role of feedback is crucial, since students need to develop their own learning strategies not just for producing language and content in any form, but also for revision and self-monitoring. In that context, they do need feedback at the discourse level.

\section{Conclusion}

This study was carried out so as to shed more light on the complexities related to providing feedback to EFL students in order to improve their writing skills. An attempt was made to explore the extent to which different types of feedback can affect the learning process. Also, one of the aims was to examine the effects of including peer feedback into the in-class activities in order to raise students' awareness regarding the importance of proofreading and revising their written assignments.

The results of the study indicate that corrective direct feedback was the preferred type of feedback, based on students' opinions in an evaluation questionnaire in this educational context. In this case, corrective feedback facilitated decreasing the number of errors related to form; however, more studies are needed, especially longitudinal ones, to investigate the long-term effects of corrective feedback on EFL students' writing skills.

Furthermore, incorporating proofreading and revision as a collaborative task as a part of in-class activities significantly affected students' readiness to take a proactive 
approach to this process and made them more aware of the need to reanalyze not only the specific features of their written product, but the global features as well, specifically content, composition, organization, the development of paragraphs and line of argumentation. This finding is actually in line with Yates and Kenkel's (2002:34) claim that teachers should tailor their feedback to the specific needs their students have at a specific level of attainment of the foreign language. Consequently, it would be very useful to integrate this process into the regular in-class activities, especially at the B2 to $C 2$ levels of language proficiency. Collaborative tasks affected proofreading and revision activities in a positive way, despite the fact that generally, students find writing a typically individual task.

The findings indicate the need for redesigning syllabi and assessment techniques so as to put more focus on assessing the process, and not only the end product of writing. At the same time, developing teamwork skills and including more collaborative-based tasks can make students more resourceful and competent in developing their own learning and self-monitoring strategies.

\section{References}

Black, P. \& Wiliam, D. (1998). Assessment and Classroom Learning. Assessment in Education, Vol. 5, No. 1,7-74.

Blagojević S. (2012). O nekim konceptima koji se različito koriste u multikulturnoj diskursnoj zajednici sa posebnim osvrtom na akademsko pisanje engleskih i srpskih autora. Teme, god. 364, br. 4, 1931-1943.

Chandler, J. (2003). The Efficacy of Various Kinds of Error Correction for Improvement of the Accuracy and Fluency of L2 Student Writing. Journal of Second Language Writing, Vol. 12, No. 3, 267-296.

Connor, U. (1996). Contrastive Rhetoric: Cross-Cultural Aspects of Second Language Writing. Cambridge: Cambridge University Press.

Council of Europe (2011). Common European Framework of Reference for Languages: Learning, Teaching, Assessment. Strasbourg: Language Policy Division. Retrieved January 10, 2018 from World Wide Web: https://www.coe.int/en/web/common-european-framework-referencelanguages

Ellis, R. (2000). Task-based Research and Language Pedagogy. Language Teaching Research, Vol. 4, No. 3, 193-220.

Fazio, L. L. (2001). The Effect of Corrections and Commentaries on the Journal Writing Accuracy of Minority- and Majority-language Students. Journal of Second Language Writing, Vol. 10, No. 4, 235-249.

Ferris, D. \& Roberts, B. (2001). Error Feedback in L2 Writing Classes: How Explicit Does it Need to Be? Journal of Second Language Writing, Vol. 10, No. 3, 161-184.

Ferris, D. (2003). Response to Student Writing. Mahwah, NJ: Lawrence Erlbaum.

Hyland, K. (2002). Teaching and Researching Writing. London: Longman.

Hyland, F. (2003). Focusing on Form: Student Engagement with Teacher Feedback. System, Vol. 31, No. 2, 217-230.

Hyland, K. \& Hyland, F. (2006). Feedback on Second Language Students'Writing. Language Teaching, Vol. 39, No. 2, 83-1001. 
Prodanović Stankić, D. · Peer Feedback as a Collaborative Task... • НВ год. LXVI бр. 3/2017, стр. 515-526.

Kroll, B. (1990). Second Language Writing: Research Insights for the Classroom. Cambridge: Cambridge University Press.

Min, H. T. (2005). Training Students to Become Successful Peer Reviewers. System, Vol. 33, No. 2, 293-308.

Nunan, D. (1999). Second Language Teaching and Learning. Boston: Heinle \& Heinle Publishers.

Nunan, D. (2004). Task-based Language Teaching. Cambridge: Cambridge University Press.

Oxford, R. (2001). Integrated Skills in the ESL/EFL Classroom. ESL Magazine, Vol. 4, No. 1, 18-20.

Silva, T. (1990). Second Language Composition Instruction: Developments, Issues, and Directions in ESL. In B. Kroll (ed.), Second Language Writing: Research Insights for the Classroom (pp. 11-23). Cambridge: Cambridge University Press.

Silva, T. (1993). Toward an Understanding of the Distinct Nature of L2 Writing: The ESL Research and its Implications. TESOL Quarterly, Vol. 27, No. 4, 657-677.

Skehan, P. (1998). A Cognitive Approach to Language Learning. Oxford: Oxford University Press.

Truscott, J. (1996). The Case against Grammar Correction in L2 Writing Classes. Language Learning, Vol. 46, No. 2, 327-369.

Truscott, J. (1999). The Case for 'the Case Against Grammar Correction in L2 Writing Classes': A Response to Ferris. Journal of Second Language Writing, Vol. 8, No. 2, 111-122.

Truscott, J. (2007). The Effect of Error Correction on Learners' Ability to Write Accurately. Journal of Second Language Writing, Vol. 16, No. 4, 255-272.

Vygotsky, L. (1978). Mind in Society: The Development of Higher Psychological Processes. Cambridge, MA: Harvard University Press.

Yates, R. \& Kenkel, J. (2002). Responding to Sentence Level Errors in Writing. Journal of Second Language Writing, Vol. 11, No. 1, 29-47.

\section{ПОВРАТНИ КОМЕНТАРИ СТУДЕНАТА КАО МАТЕРИЈАЛ ЗА УЧЕЊЕ ЗАСНОВАНО НА КОНКРЕТНОМ ЗАДАТКУ РАДИ УНАПРЕЪИВАҢА ВЕШТИНЕ ПИСАҢА НА СТРАНОМ ЈЕЗИКУ: СТУДИЈА СЛУЧАЈА}

\footnotetext{
Айсйракй Писане на енглеском као страном језику представља једну од основних вештина за све оне који учествују у академском дискурсу. Потешкоће у вези са писањем са којима се сусрећу ученици су засноване на пресликавану језичких структура матерњег језика на страни, организацији текста и начину навођења аргумената. У контексту усвајања вештина адекватни и циљани повратни коментари наставника као и начин на који се исправљају грешке имају велики утицај на усавршавање вештине писања. Циљ ове студије случаја био је да се испитају ставови студента у вези са повратним коментарима да би се утврдило какав утицај они имају на писање студената на страном језику. Такође, ииљ је био да се студенти кроз заједнички рад на анализи повратних коментара подстакну да унапреде своје вештине. У истраживану су коришћене квантитативне методе (дескриптивна статистичка метода) и квалитативне. Резултати истраживања показују да су позитивни
} 
ставови према одређеној врсти повратних коментара наставника условљени културом као и да сарадюа у току рада заснованом на задацима има позитиван утицај на усавршаване појединачних компетенција везаних за писање али и критичку анализу написаног. У складу са добијеним резултатима, ураду се предлаже укључиване оваквих активности уплан и програм наставе у већој мери, као и унапређиване метода оченивана тако да се подстакне саморегулисано учење код студената.

Кључне речи: Енглески као страни језик, писање на страном језику, повратни коментари, учене засновано на задацима.

\title{
КОММЕНТАРИИ СТУДЕНТОВ КАК УЧЕБНЫЙ МАТЕРИАЛ ОСНОВАННЫЙ НА КОНКРЕТНЫХ ЗАДАНИЯХ В ЦЕЛЯХ УЛУЧШЕНИЯ НАВЫКОВ ПИСЬМА НА ИНОСТРАННОМ ЯЗЫКЕ: ИЗУЧЕНИЕ СЛУЧАЯ
}

\begin{abstract}
Резюме Пользование английским языком как иностранным в письменном виде является одним из основных умений для всех, кто участвует в академическом дискурсе. Трудности в связи с письмом, с которыми сталкиваются учащиеся, основаны на влиянии языковых структур родного на иностранный язык, на организацию текста и способ аргументации. В контексте приобретения навыков, адекватные и целенаправленные комментарии пеподавателя, атакжеспособыисправления ошибок, оказывают существенное влияние на улучшение навыков письма. Цель данного исследования заключается в изучении отношения студентов кответным комментариям и определения ихвлияния на приобретение навыков письма на иностранном языке. Кроме того, хотелось, таким образом в совместной работе побудить у учащихся желание улучшить свои навыки и умения. В исследовании использованы количественные (дескриптивный и статистический) и качественные методы. Результаты исследования показывают, что положительное отношение к определенному типу коммуникации с преподавателем обусловлено культурой, что сотрудничество в обучении, основанном на заданиях, оказывает положительное влияние на улучшение индивидуальных компетенций, связанных с обучением письму, а также и на критический анализ написанного. В соответствии с полученными результатами в статье рекомендуется включение такой деятельности в учебную программу и учебный план, а также улучшение методов оченки и поощрение саморегулируемого обучения среди учащихся.
\end{abstract}

Ключевыеслова: английский язык как иностранный, обучение письму, комментарий, обучение на основе заданий. 